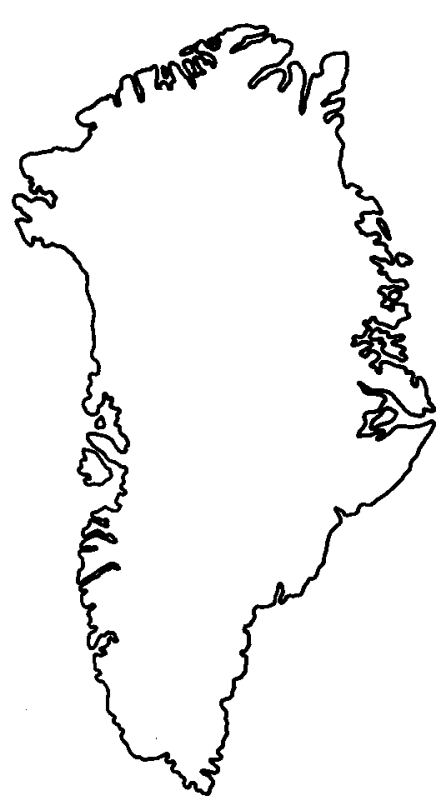

\title{
Cambro-Ordovician rocks of C. H. Ostenfeld Nunatak, northern East Greenland
}

\author{
Peter Frykman
}

More than $3000 \mathrm{~m}$ of Cambro-Ordovician carbonates on C. H. Ostenfeld Nunatak are assigned to the Hyolithus Creek, Dolomite Point, Antiklinalbugt, Cape Weber, Narwhale Sound and Heim Bjerge Formations. The great thickness of the Heim Bjerge Formation suggests that the highest beds of the Cambro-Ordovician sequence on the nunatak may be the youngest Lower $\mathrm{Pa}$ laeozoic rocks known from the East Greenland part of the Caledonides. The carbonates are faulted in contact with Precambrian sediments, and unconformably overlain by Devonian conglomerate.

P. F. Institut for Historisk Geologi og Palceontologi, Øster Voldgade 10, DK-1350, Kabenhavn K., Danmark.

In connection with a micropalaeontological collecting programme centred around the classic Cambro-Ordovician sequences in Albert Heim Bjerge and on Ella $\varnothing$, a visit was paid in 1977 to the poorly known sequence exposed on C. H. Ostenfeld Nunatak, northern East Greenland (fig. 1). The nunatak is located in the middle of Wordie Gletscher and forms one of the northernmost exposures of Cambro-Ordovician rocks in East Greenland. The overall topography is gently rounded, with most exposures of the easterly dipping limestones and dolomites which comprise much of the sequence being located on typical roches moutonnées. A $1 \mathrm{~km}$ wide valley running north-south through the southern part of the nunatak follows the outcrop of the Narwhale Sound Formation, a strongly banded carbonate sequence presumably readily attacked by glacial erosion.

As noted previously (Frykman, 1978), the Cambro-Ordovician sequence on C. H. Ostenfeld Nunatak comprises the Hyolithus Creek, Dolomite Point, Cass Fjord (subsequently renamed Antiklinalbugt, see Peel \& Cowie, this report), Cape Weber, Narwhale Sound and Heim Bjerge Formations (fig. 2). Previously, the presence of only two of these formations, namely the Hyolithus Creek and Cass Fjord Formations had been established (Cowie \& Adams 1957, p. 45). These authors' information was obtained from J. Haller who made a short visit to the nunatak in 1956, establishing the presence of Precambrian as well as Cambro-Ordovician strata. C. H. Ostenfeld Nunatak has apparently not been visited by geologists since Haller's visit. In view of the restricted information available, it is clear that the maps of the nunatak presented by Koch \& Haller (1971) and Haller $(1970,1971)$ are of a preliminary character.

Precambrian strata on C. H. Ostenfeld Nunatak consist of deposits of the Eleonore Bay 


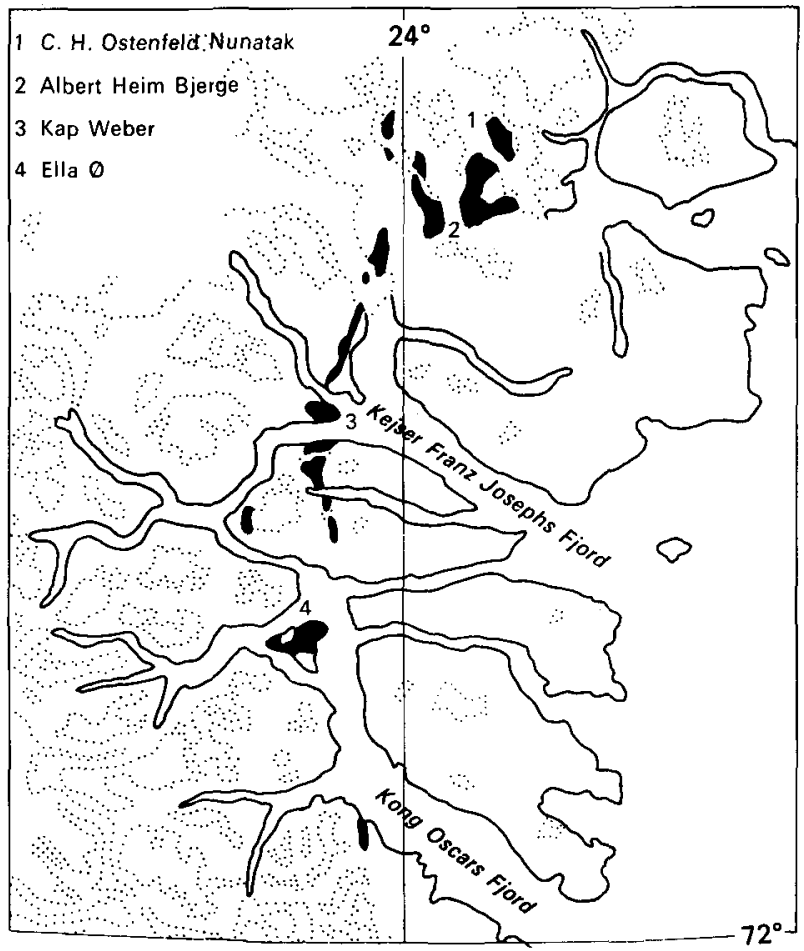

Fig. 1. Sketch map of northern East Greenland showing outcrops of Cambro-Ordovician strata (black).

Group and the Tillite Group (Haller, 1971; Koch \& Haller, 1971). Devonian rocks were recognised on the nunatak for the first time in 1977. They overlie the Ordovician in the easternmost area where a small badly weathered outcrop consists of coarse conglomerates with $5-50 \mathrm{~cm}$ long limestone clasts set in a reddish coloured matrix. The limestone clasts are subangular to subrounded in the upper part and consist mainly of very hard, fine grained limestone with a weak greenish colouration. This lithology has not been recognised in the Cambro-Ordovician sequence. The conglomerate shows a trace of bedding in the lowermost part of the exposure, but is otherwise massive. The contact with the underlying Ordovician is not exposed.

In the south-western corner of the nunatak, a small intrusion occurs in the Cape Weber Formation. It is apparently a thin lamprophyre dyke (Niels Hald, written comm., 1979), wedging out towards the centre of the nunatak. However, it has seemingly been sheared, since it is now exposed in five separate units.

\section{Structure}

C. H. Ostenfeld Nunatak was found to be structurally more simple than suggested by Haller (1970) and Koch \& Haller (1971). As noted by these authors, the main structural unit is a block of Cambro-Ordovician sediments limited to the east and west by north-south trending faults. Precambrian sediments are brought into contact with Cambro-Ordovician sediments along both faults. Within the Cambro-Ordovician block the entire sequence dips uniformly to the east (fig. 
Fig. 2. Precambrian-Devonian sequence on C. H. Ostenfeld Nunatak.

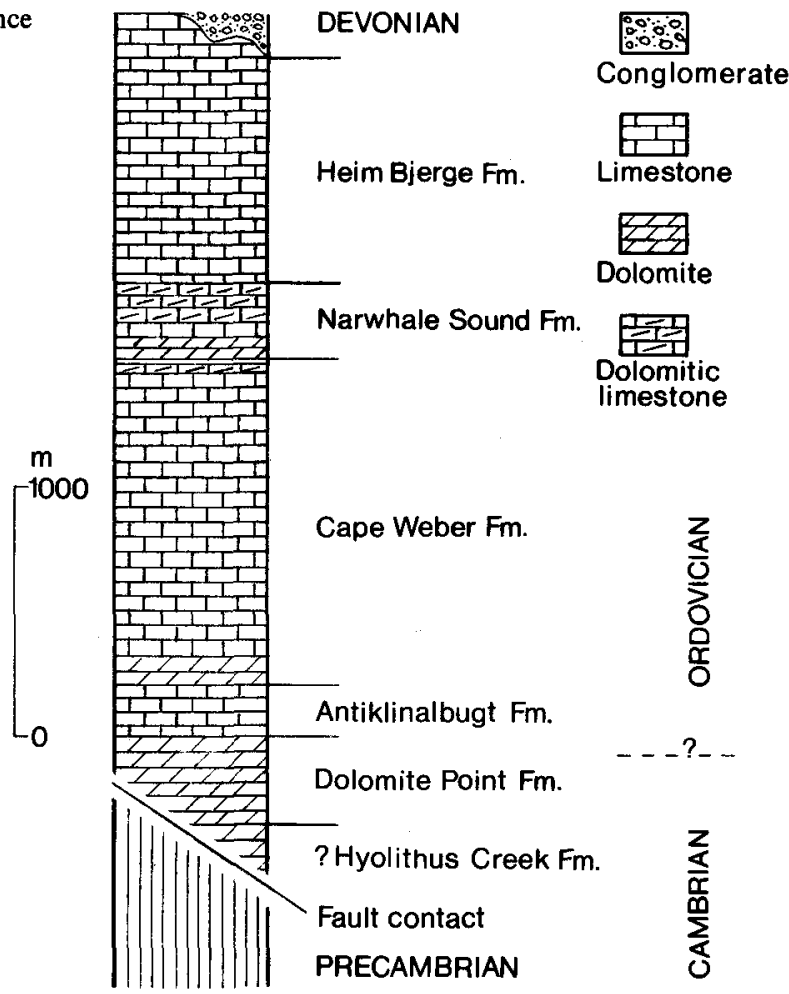

3) whereas Haller (1970) noted two anticlines and two synclines. In the more simple model outlined here, the Cambrian deposits mapped by Koch \& Haller are restricted to the western part of the nunatak. The sequence in the east where the Heim Bjerge Formation is much thicker than is recorded from elsewhere in East Greenland, may reach stratigraphic levels well above those previously known to have been deposited before the onset of Caledonian deformation and orogenesis in this immediate area. However, Silurian strata are present in the Caledonian foreland in North-East Greenland, more than $400 \mathrm{~km}$ to the north (Henriksen \& Higgins, 1976).

\section{Cambro-Ordovician stratigraphy}

In the following discussion, the stratigraphic scheme proposed by Cowie \& Adams (1957) is followed, with modifications proposed by Peel \& Cowie (this report). However, the spelling of lithostratigraphic names follows Poulsen (1930), rather than Cowie \& Adams. The latter authors changed some spellings in accordance with changes in the spelling of the geographic localities.

The Cambro-Ordovician carbonate sequence on $\mathrm{C}$. $\mathrm{H}$. Ostenfeld Nunatak ranges from the Hyolithus Creek Formation to the Heim Bjerge Formation (fig. 2). The different formations are easily recognised from the section in Albert Heim Bjerge, only $20 \mathrm{~km}$ away, although some variation in lithology and thickness is evident. The Hyolithus Creek Formation was not observed in the field during the 1977 visit but its presence is anticipated. This is supported by Cowie \& 


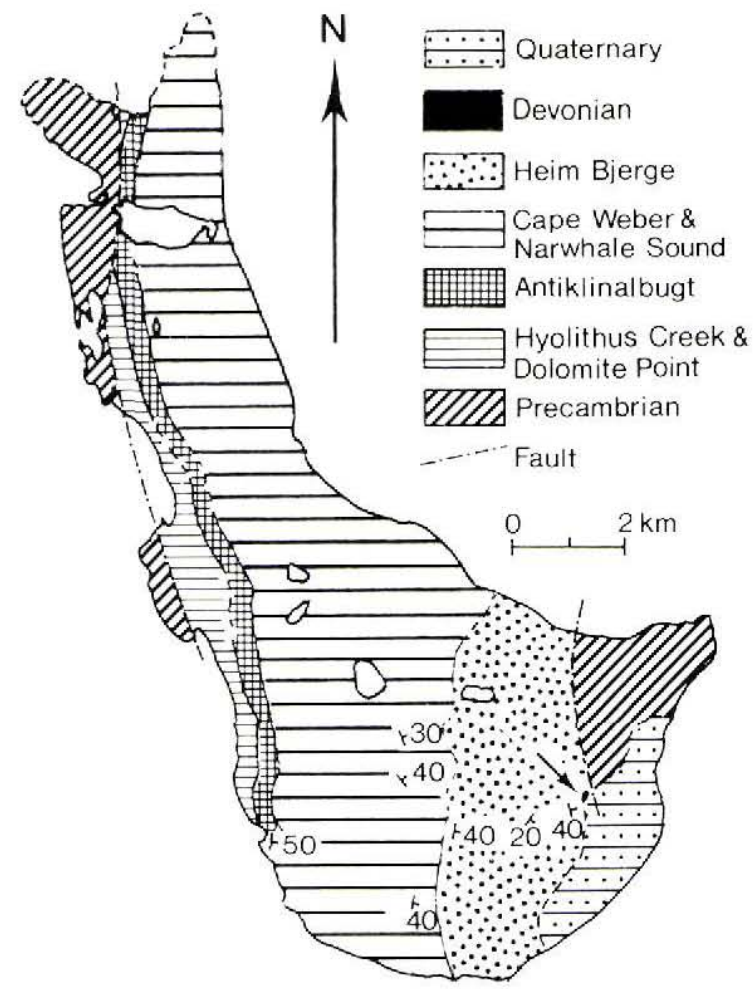

Fig. 3. Geological map of C. H. Ostenfeld Nunatak. The topographic outline is based on Geodetic Institute air photographs route $871 \mathrm{D}$ no. 819 , and $871 \mathrm{E}$ no. 784 .

Adams (1957, footnote p. 45) who stated that John Haller collected fossils (Salterella) which, together with their matrix, suggest the presence of the Hyolithus Creek Formation. In Albert Heim Bjerge (fig. 1), the formation is composed of massive, dark grey to black dolomites with abundant stylolitic seams.

\section{Dolomite Point Formation (Cambrian - Early Ordovician)}

The upper part, which is the only portion of the approximately $300 \mathrm{~m}$ thick formation actually investigated during 1977 , is dominated by thinly bedded, grey silty dolomites with occasional light grey nodules or lenticles of chert. Wavy and lenticular bedding are frequent while, at certain horizons, the dolomites are cavernous and stylolitic.

The boundary with the overlying Antiklinalbugt Formation is marked by a distinct change from light dolomites to dark limestones. Two metres below this boundary a $10 \mathrm{~cm}$ thick bed of dark, conglomeratic, dolomitic limestone associated with $10 \mathrm{~cm}$ of finely laminated dolomite is found in the otherwise uniform dolomites. The dark conglomeratic bed has yielded Early Ordovician conodonts (written comm. to GGU from V. E. Kurtz, 1978). This proposed Ordovician age for at least part of the Dolomite Point Formation is in marked contrast to previous assumptions of a Cambrian age (Cowie, 1971). It should be pointed out, however, that no angular discordance has been detected between strata of the Dolomite Point and Antiklinalbugt Formations 
in Albert Heim Bjerge (Cowie \& Adams, 1957) and likewise no such features or erosional phenomena were observed in connection with the boundary in the section on C. H. Ostenfeld Nunatak.

\section{Antiklinalbugt Formation (Early Ordovician)}

The name Antiklinalbugt Formation was proposed by Peel \& Cowie (this report) as a replacement name for the so-called Cass Fjord Formation of East Greenland (Poulsen, 1930; Cowie \& Adams, 1957). The Cass Fjord Formation was restricted to the general area of the type sequence, in north-western Greenland and adjacent Bache Peninsula (Canada).

The formation is approximately $200 \mathrm{~m}$ thick and is characteristically an alternation of prominent, dark, well bedded limestone and rubbly weathering, silty, nodular limestone with greygreen weathering colours. Parts of the formation dominated by the silty limestone are poorly exposed due to the rubbly weathering. The upper $50 \mathrm{~m}$ of the formation shows a gradual transition into the more massive limestones of the Cape Weber Formation.

Fig. 4. Comparative sections through the Antiklinalbugt and lower Cape Weber Formations in northern East Greenland. Letters correspond to units recognised in fig. 5 , and discussed in the text. (Sections from Ella $\varnothing$ and Albert Heim Bjerge based on Cowie \& Adams, 1957).

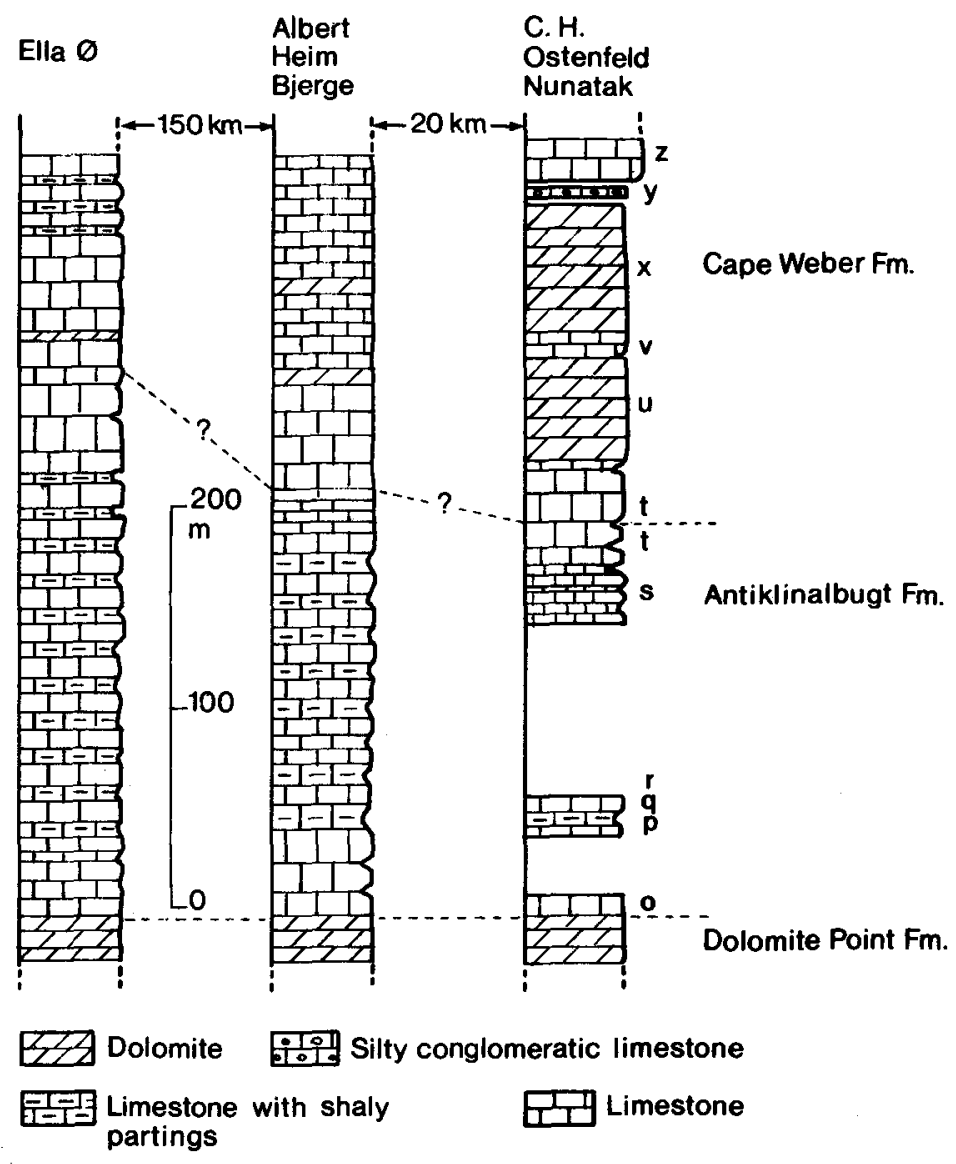




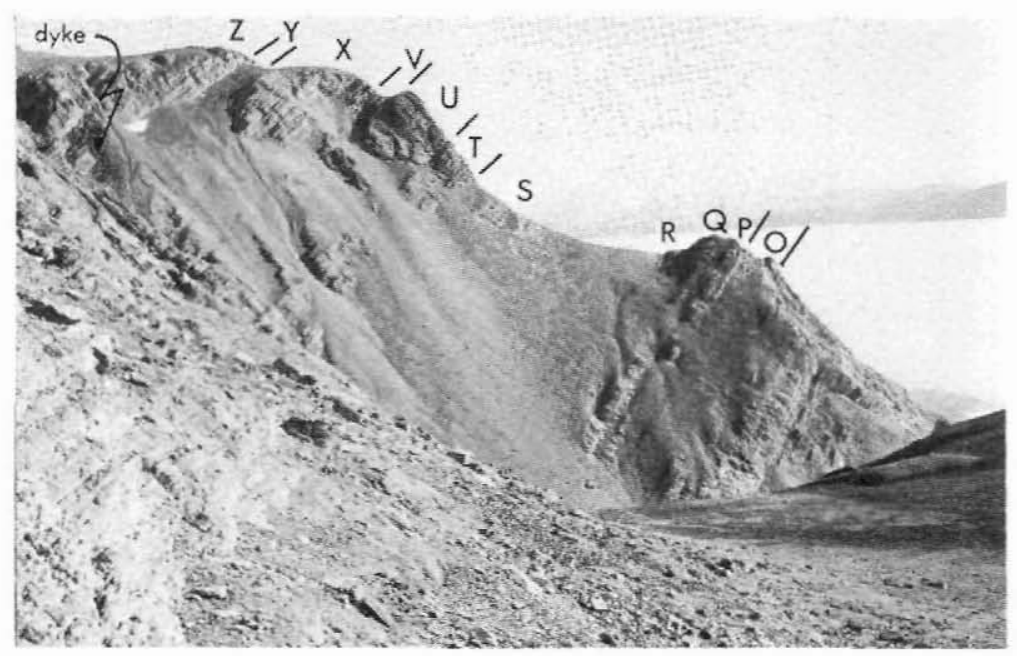

Fig. 5. Cambro-Ordovician strata at the south-western end of C. H. Ostenfeld Nunatak. For explanation of letters see fig. 4 .

\section{Cape Weber Formation (Early Ordovician)}

This formation, referred to as the Kap Weber Formation by Cowie \& Adams (1957), comprises a thick $(c .1750 \mathrm{~m})$ sequence of massive limestones and dolomitic limestones, with subordinate dolomites (figs 2,4 ). In the lower part, a sequence of $120 \mathrm{~m}$ of light to dark grey dolomites includes $10 \mathrm{~m}$ of pure limestone in the middle (figs 4,5 , beds $\mathrm{U}, \mathrm{V}, \mathrm{X}$ ). The dolomites are hard, well bedded, topographically prominent and form two marker beds (figs 5,6 ). The upper bed is more resistant, possibly due to the presence of several silicified horizons.

This dolomitic interval in the lower Cape Weber Formation is less well developed in Albert Heim Bjerge and on Ella $\varnothing$ (fig. 1). Cowie \& Adams (1957) recorded only a few thin bands of dolomite and some dolomitic limestone in the otherwise limestone sequence from Albert Heim Bjerge. The 1977 field work confirmed their observation and also indicated that a similar situation prevails on Ella $\varnothing$. A thin poorly exposed clastic interval ( $\mathrm{Y}$ in figs, 4,5) overlying the dolomite shows a similar restricted distribution. It contains fossiliferous, silty, conglomeratic greenish limestone and red to brown conglomerates.

Above this interval, the rest of the formation is composed of the more typical massive, dark limestone ( $\mathrm{Z}$ in figs 4,5 ) which often contains isolated nodules and bands of chert. In the lower part of the formation, the bands of chert nodules are often distributed in a distinctive cyclic pattern (fig. 7). Each cycle commences with a few distinct bands of chert nodules in an otherwise homogeneous limestone. The nodules are gradually replaced by a more disseminated silicification while, in some examples, the cycle is terminated by a strongly silicified bed of limestone with a mottled, sandy appearance.

The upper part of the Cape Weber Formation is badly exposed and the transition to the Narwhale Sound Formation was not observed. 
Fig. 6. Ordovician strata at the south-western end of C. H. Ostenfeld Nunatak. The cliffforming unit to the left is formed by the Antiklinalbugt Formation; the cliffs in the centre and to the right are formed by the Cape Weber Formation.

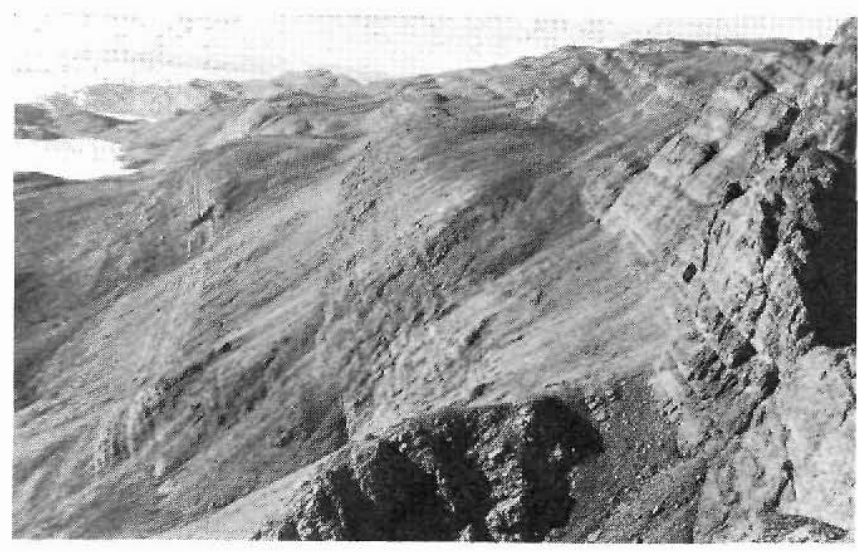

Fig. 7. Chert bands and silification in the Cape Weber Formation on C. H. Ostenfeld Nunatak.

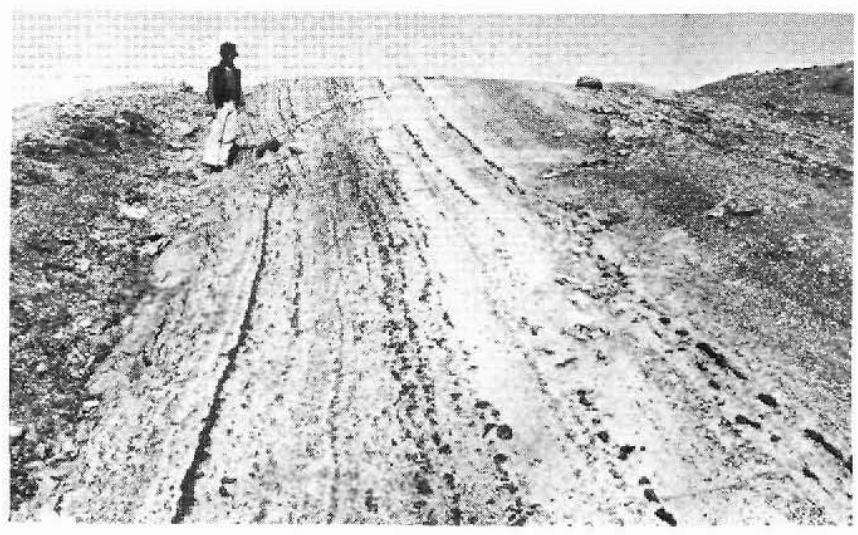

\section{Narwhale Sound Formation (Early - ?Middle Ordovician)}

The Narwhale Sound Formation $(c .500 \mathrm{~m}$ ) is poorly exposed and only the uppermost $150 \mathrm{~m}$ were examined. It is easily eroded, as witnessed by the prominent north-south valley on the nunatak along the strike of the formation. Well bedded carbonates of various lithologies dominate with beds of intraformational conglomerate alternating with mottled dolomitic limestones and algal laminated limestones. The uppermost $50 \mathrm{~m}$ show a transition to the thicker bedded, uniform limestones typical of the Heim Bjerge Formation.

\section{Heim Bjerge Formation (Middle - ?Late Ordovician)}

This formation is composed of a monotonous sequence of rather uniform, thick bedded, light grey limestone. In addition to not being recorded before the 1977 field season, the occurrence of the Heim Bjerge Formation on C. H. Ostenfeld Nunatak is notable on account of the thickness of strata preserved, more than $1200 \mathrm{~m}$. In Albert Heim Bjerge only $320 \mathrm{~m}$ remain, while the formation is absent altogether on Ella $\varnothing$. Confirmatory fossil evidence is not yet available, but it is 
probable that the C. H. Ostenfeld Nunatak sequence includes the youngest Ordovician strata from East Greenland.

Acknowledgements. J. S. Peel, E. Hảkansson and A. K. Higgins assisted substantially in the preparation of the manuscript. H. Egelund draughted the figures. Lars Trolle assisted during the fieldwork.

\section{References}

Cowie, J. W. 1971: The Cambrian of the North American arctic regions. In Holland, C. H. (edit.) Cambrian of the New world 325-383. London: Interscience.

Cowie, J. W. \& Adams, P. J. 1957: The geology of the Cambro-Ordovician rocks of central East Greenland. 1. Meddr Grønland 153 (1), $193 \mathrm{pp}$.

Frykman, P. 1978: Investigation of Lower Palaeozoic rocks in northern East Greenland. Rapp. Grønlands geol. Unders. 90, 107-109.

Haller, J. 1970: Tectonic map of East Greenland $(1: 500,000)$. An account of tectonism, plutonism, and volcanism in East Greenland. Meddr Grønland 171 (5), 286 pp.

Haller, J. 1971: Geology of the East Greenland Caledonides. 413 pp. New York: Interscience Publishers.

Henriksen, N. \& Higgins, A. K. 1976: East Greenland Caledonian fold belt. In Escher, A. \& Watt, W. S. (edit.) Geology of Greenland, 182-246. Copenhagen: Geol. Surv. Greenland.

Koch, L. \& Haller, J. 1971: Geological map of East Greenland $72^{\circ}-76^{\circ}$ N. Lat. (1:250,000). Meddr Grønland 183, $26 \mathrm{pp}$.

Poulsen, C. 1930: Contributions to the stratigraphy of the Cambro-Ordovician of East Greenland. Meddr Grønland 74 (12), 297-316. 